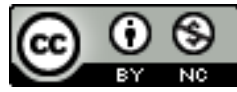

JurnalPendidikanIlmu Pengetahuan Sosial Indonesia is licensed under A Creative Commons Attribution-Non Commercial 4.0 International License.

\title{
PENGARUH GAYA KEPEMIMPINAN KEPALA SEKOLAH, MOTIVASI BERPRESTASI DAN IKLIM SEKOLAH TERHADAP KINERJA GURU DI MAN 2 KABUPATEN PROBOLINGGO
}

\author{
Muh. Husen Arifin ${ }^{1)}$ \\ ${ }^{1)}$ Politeknik Al-Islam Bandung \\ E-mail: husenarifin2889@gmail.com
}

\begin{abstract}
Abstrak. Penelitian ini bertujuan mengetahui pengaruh kepemimpinan kepala sekolah, motivasi berprestasi, iklim sekolah terhadap kinerja guru dan karyawan MAN 2 Kabupaten Probolinggo. Penelitian ini menggunakan pendekatan deskriptif kuantitatif sebelumnya dilakukan uji korelasi product moment untuk uji validitas. Sampel yang diambil yaitu 39 guru MAN 2 Kabupaten Probolinggo. Hasil penelitian menyimpulkan ada pengaruh yang signifikan antara kepemimpinan kepala sekolah, motivasi berprestasi dan iklim sekolah terhadap kinerja guru MAN 2 Kabupaten Probolinggo besarnya pengaruh secara simultan $(93,2 \%)$. Besarnya pengaruh secara parsial antara kepemimpinan kepala sekolah terhadap kinerja guru $(10,1 \%)$, antara motivasi berprestasi terhadap kinerja guru $(8,6 \%)$ dan besarnya pengaruh antara iklim sekolah terhadap kinerja guru $(16,3 \%)$.
\end{abstract}

Keywords: Kepemimpinan Kepala Sekolah, Motivasi Berpretasi, Iklim Sekolah, Kinerja Guru

\section{PENDAHULUAN}

Guru merupakan salah satu unsur di bidang kependidikan harus berperan secara aktif dan menempatkan kedudukannya sebagai tenaga profesional, sesuai dengan tuntutan masyarakat yang semakin berkembang. Dalam hal ini guru tidak sematamata sebagai pengajar yang melakukan transfer ilmu pengetahuan, tetapi juga sebagai pendidik yang melakukan transfer nilai-nilai sekaligus sebagai pembimbing yang memberikan pengarahan dan menuntun siswa dalam belajar.

Tugas pokok guru diwujudkan dalam kegiatan belajar mengajar serta tugas-tugas guru dalam kelembagaan marupakan bentuk kinerja guru. Apabila kinerja guru meningkat, maka berpengaruh pada kualitas keluaran atau outputnya. Oleh karena itu perlu dukungan dari berbagai pihak sekolah untuk meningkatkan kinerja guru.Kinerja guru akan menjadi optimal, bilamana diintegrasikan dengan komponen sekolah, baik itu kepala sekolah, lingkungan sekolah, guru, karyawan maupun anak didik.

Kepemimpinan Kepala Sekolah MAN 2 Kabupaten Probolinggo secara umum sudah cukup baik, dimana Kepala Sekolah memiliki motivasi yang tinggi untuk memajukan sekolah yang dipimpinnya. Hal tersebut ditunjukkan dengan penambahan fasilitas atau media pembelajaran agar proses pembelajaran berjalan lebih efektif. Namun bagi sebagian besar guru, disiplin yang diterapkan menjadi beban tersendiri dalam bekerja.

Lingkungan Sekolah di MAN 2 Kabupaten Probolinggo terutama dimensi hubungan masih perlu ditingkatkan. Dalam dimensi hubungan yang perlu ditingkatkan adalah interaksi antara guru dengan Kepala Sekolah. Interaksi dari atas ke bawah kebanyakan hanya berupa perintah. Sedangkan interaksi dari bawah ke atas, guru hanya menyampaikan laporan hasil belajar siswa maupun hasil kerja dari tugas-tugas lain yang dibebankan kepadanya. Hubungan yang terjadi antara Kepala Sekolah dengan guru cenderung kaku. Hal tersebut dapat terlihat dari kurangnya keterbukaan dalam komunikasi antara Kepala Sekolah dengan guru di MAN 2 Kabupaten Probolinggo.

Kepala Sekolah merupakan personel sekolah yang bertanggug jawab terhadap seluruh kegiatan-kegiatan sekolah (Daryanto, 2005).

Motivasi berprestasi adalah dorongan yang berasal dari dalam diri orang-orang untuk berprestasi dan berusaha berprestasi dalam upaya untuk mencapai tujuan. Motivasi berprestasi dapat dikembangkan di suatu organisasi kependidikan dimana kebutuhan untuk menyelesaikan masalah adalah tinggi. Guru-guru akan bekerja lebih baik jika mereka sungguh-sungguh diberi motivasi.

Iklim sekolah terjadi adanya interaksi antara struktur organisasi yang terbuka, standar kinerja yang dinamis, rasa tanggung jawab guru, keikutsertaan guru dalam organisasi, pengakuan atas hasil pekerjaan, gaya manajemen yang mendukung dan komitmen dalam mengemban tugas.

Kinerja guru yang baik tentunya tergambar pada penampilan mereka baik dari penampilan kemampuan akademik maupun kemampuan profesi menjadi guru artinya mampu mengelola pengajaran di dalam kelas dan mendidik siswa di luar kelas dengan sebaik-baiknya. 
Pernyataan di atas yang melatarbelakangi penulis melakukan penelitian tentang Pengaruh Gaya Kepimpinan Kepala Sekolah, Motivasi Berprestasi dan Iklim Sekolah Terhadap Kinerja Guru di MAN 2 Kabupaten Probolinggo.

\section{METODE}

Penelitian ini menggunakan metode survei asosiatif, untuk mencari pengaruh pada penelitian ini adalah seluruh guru MAN 2 Kabupaten Probolinggo yaitu sejumlah39 guru, dengan pengambilan sampel metode total sampling. Variabel dalam penelitian ini adalah variable terikat dan variabel bebas dan karena penelitian ini untuk mengetahui pengaruh kepemimpinan sekolah, motivasi berprestasi dan iklim sekolah terhadap kinerja guru di MAN 2 Kabupaten Probolinggo.

\section{ANALISIS DATA}

Analisis data pada penelitian ini untuk mengetahui untuk mendeskripsikan masing-masing variabel bebas, yaitu variabel kepemimpinan kepala sekolah, motivasi berprestasi dan iklim (lingkungan) sekolah, dan variabel terikat yaitu kinerja guru. Untuk mengetahui tingkat persentase skor jawaban dari masing-masing guru dapat dihitung dengan menggunakan rumus sebagai berikut:

$$
\text { Persentase skor }(\%)=\frac{n}{N} \times 100 \%
$$

Rumus menghitung persentase skor jawaban

Sehingga dari rumus dapat menentukan kategori atau jenis deskriptif persentase yang diperoleh masing-masing indikator dalam variabel. Kemudian mencari persamaan regresi linier berganda dengan mencari persamaan regresi dan uji hipotesis keterpengaruhan kepemimpinan kepala sekolah, motivasi berprestasi dan iklim (lingkungan) sekolah dengan kinerja guru secara parsial dan simultan. Adapun uji validitas dengan menggunakan korelasi product moment.

\section{HASIL DAN PEMBAHASAN}

Hasil dari penelitian ini yaitu untuk mengetahui pengaruh gaya kepemimpinan sekolah, motivasi berprestasi dan iklim sekolah pada kinerja guru di MAN 2 Kabupaten Probolinggo dan berdasarkan dari responden maka berdasarkan hasil persamaan regresi yang diperoleh dimana koefisien regresi bertanda positif maka dapat diartikan bahwa terdapat pengaruh positif antara kepemimpinan kepala sekolah, motivasi berprestasi dan iklim sekolah terhadap kinerja guru dengan besarnya pengaruh secara simultan adalah 93,2\%. Besarnya pengaruh secara parsial antara kepemimpinan kepala sekolah terhadap kinerja guru adalah $10,1 \%$ antara motivasi berprestasi terhadap kinerja guru adalah 8,6\% dan besarnya pengaruh antara lingkungan sekolah terhadap kinerja guru adalah $16,3 \%$.

Diantara kepemimpinan kepala sekolah, motivasi berprestasi dan iklim sekolah, yang memberikan pengaruh lebih dominan terhadap kinerja guru MAN 2 Kabupaten Probolinggo adalah iklim sekolah. Iklim sekolah merupakan variabel yang sangat berpengaruh terhadap kinerja guru. Lingkungan sekolah yang baik di MAN 2 Kabupaten Probolinggo menyangkut hubungan antar personal sekolah, kesempatan pengembangan diri, kesempatan untuk ikut berperan dalam perubahan sistem serta kondisi lingkungan sekolah yang nyaman dapat memotivasi para guru untuk lebih giat dalam melaksanakan tugasnya yang akan berdampak pada peningkatan kinerja guru.

Kepemimpinan kepala sekolah pun merupakan variabel yang ikut berpengaruh terhadap kinerja guru. Hal ini terlihat dari banyaknya responden yang menyatakan kepemimpinan kepala sekolah telah baik.

Faktor motivasi berprestasi guru merupakan variabel yang ikut berpengaruh terhadap kinerja guru namun motivasi berprestasi yang baik di MAN 2 Kabupaten Probolinggo hanya menyangkut honorarium yang sesuai, terjalinnya kerja sama yang baik antar guru, penghargaan yang sesuai, aktualisasidiri yang baik dan memiliki kepuasan dalam lingkungan kerjaakan berdampak pada peningkatan kinerja guru.

\section{KESIMPULAN}

1. Berdasarkan penelitian terdapat pengaruh yang signifikan kepemimpinan sekolah terhadap kinerja guru menunjukkan perolehan $t_{\text {hitung }}$ 3,332 dengansig0,002. Variabel motivasi berprestasi guru memperoleh $t_{\text {hitung } 3,180 \text { dengansig0,003. Sedangkan untuk variabel }}$ iklim (lingkungan) sekolah memperoleh $t_{\text {hitung }} 3,874$ dengan sig0,000.

\section{REFERENCES}

Arifin, R. d. (2003). Perilaku Organisasi. Malang: Bayu Media.

Arikunto, S. (2005). Manajemen Penelitian. Jakarta : Rineka Cipta.

Arni, M. (2001). Komunikasi Organisasi. Jakarta: Bumi Aksara.

Brophy, J. R. (1998). Educational Psychology. New York: Longman.

Daryanto, H. M. (2006). Administrasi Pendidikan. Jakarta: PT Rineka Cipta.

Davis K, N. (2001). Perilaku dalam Organisasi Jilid 1. Jakarta: Erlangga.

Hasibuan, S. (2000). Manajemen Sumber Daya Manusia. Jakarta: Bumi Aksara.

Jauhari, A. (2005). Manajemen Kerja. Jakarta: Gramedia Pustaka.

Makmun, A. S. (2009). Psikologi Kependidikan Perangkat Sistem Pengajaran Modul . Bandung: PT Remaja Rosdakarya.

Moekijat. (2001). Manajemen Kepegawaian. Bandung: Alumni.

Mulyasa, E. (2004). Menjadi Kepala Sekolah Profesional dalam Konteks Menyukseskan MBS dan KBK. 
Bandung: PT Remaja Rosda Karya.

Pareek, U. (1999). Perilaku Organisasi. Jakarta: Karya Unipress.

Pidarta, M. (1988). Pemikiran Tentang Supervisi Pendidikan. Bandung: Jemmars.

Sardiman. (2005). Interaksi dan Motivasi Belajar Mengajar. Jakarta: PT Raja Grafindo Persada.

Steers, R. (2000). Efektivitas Organisasi. Jakarta: Erlangga.

Sudjana, N. (1996). Metoda Statistika . Bandung: Tarsito.

Sugiyono. (1999). Statistika Penelitian. Bandung : CV Alfabeta.

Sujak, A. (2000). Kepemimpinan Manajer. jakarta: Rajawali Press.

Sulistiani, T., \& Rosidah, A. (2009). Manajemen Sumber Daya Manusia. Yogyakarta: Graha Ilmu.

Wahab, R. (1999). Perkembangan Belajar Peserta Didik. Jakarta: Depdikbud.

Wahjosumidjo. (1998). Kepemimpinan dan Motivasi. Jakarta: Ghalia Indonesia.

Wahjosumidjo. (2003). Kepemimpinan Kepala Sekolah, Tinjauan Teoritik dan Permasalahannya. Jakarta: PT Raja Grafindo Persada.

Wahyudin. (2008). Pembelajaran dan Model-Model Pembelajaran (Pelengkap untuk Meningkatkan Kompetensi Pedagogis Para Guru dan Calon Guru Profesional). Jakarta: CV IPA Abong.

Wayne, P., \& Don, F. (2000). Komunikasi Organisasi. Bandung: Remaja Rosdakarta.

Winardi , J. (2001). Pemotivasian dalam Manajemen . Jakarta: PT Raja Grapindo Persada.

Yulaelawati, E. (2007). Kurikulum dan Pembelajaran Filosofi Teori dan Aplikasi. Jakarta: Pakar Karya. 